\title{
ДИНАМІКА БІОХІМІЧНИХ ПОКАЗНИКІВ СИРОВАТКИ КРОВІ У ТВАРИН З МОДЕЛЬОВАНИМ ПАРОДОНТИТОМ НА ТЛІ ЕКСПЕРИМЕНТАЛЬНИХ УРАЖЕНЬ ШЛУНКОВО-КИШКОВОГО ТРАКТУ
}

У тварин груп дослідження з модельованим пародонтитом при експериментально викликаних ураженнях шлунково-кишкового тракту досліджували вміст у сироватці крові білка, малонового діальдегіду, каталази; визначали загальну протеолітичну активність та антиоксидантно-прооксидантний індекс. Встановлено, що у групах експериментальних щурів підвищуються вміст білка, малонового діальдегіду й активність протеаз при зниженні активності каталази та антиоксидантно-прооксидантного індексу, причому дана тенденція більш виражена у тварин з модельованим пародонтитом на тлі експериментальних уражень шлунково-кишкового тракту.

КЛЮЧОВІ СЛОВА: пародонтит, шлунково-кишковий тракт, білок, загальна протеолітична активність, каталаза, малоновий діальдегід.

ВСТУП. Стан і взаємодія основних регуляторних систем визначають гомеостаз організму і його резистентність на будь-який патогенний вплив, а багатофакторна модель виникнення причин хвороб констатує, що всі хвороби - результат складної взаємодії біологічних, психічних, соціальних та інших факторів $[2,4,5]$. Необхідно враховувати той факт, що всі системні захворювання, якими, зокрема, $€$ захворювання шлунково-кишкового тракту, змінюючи реактивність організму тією чи іншою мірою, сприяють виникненню та прогресуванню стоматологічної патології - карієсу і запальних захворювань пародонта $[1,2,5]$.

Ступінь запально-деструктивних процесів у пародонті корелює з активністю запалення в шлунково-кишковому тракті, що може бути єдиним процесом запального генезу, який реалізується з участю дифузної нейроендокринної системи травного тракту, з одного боку, а з іншого - через процеси проліферації та апоптозу епітеліоцитів [3, 7].

Ряд авторів розглядає порожнину рота як своєрідну екологічну систему, в якій різні чинники (загальні й місцеві), спільно взаємодіючи, викликають різноманітні патологічні процеси. Зміни в порожнині рота відображають закономірності патогенезу системної патології і зумовлені етіологічною, морфологічною та функціональною інтеграцією всіх систем орга-

() І. Є. Швець, В. Т. Дирик, М. Т. Слобода, 2015. нізму $[1,3,5] . ~ 3$ цієї причини проблема діагностики та лікування патології органів порожнини рота виходить за межі стоматології, а знання особливостей проявів захворювань внутрішніх органів у порожнині рота важливе для лікаря-стоматолога з метою діагностики та розробки комплексних підходів при лікуванні даної патології.

Метою дослідження було вивчити біохімічні показники сироватки крові у тварин з модельованим пародонтитом на тлі експериментальних уражень шлунково-кишкового тракту.

МЕТОДИ ДОСЛІДЖЕННЯ. Для експериментальних досліджень використовували білих щурів лінії Вістар з урахуванням однотипних умов утримування для всіх груп тварин, залежно від мети дослідження, з експериментальним раціоном харчування, який зумовлював розвиток пародонтиту в тканинах пародонта. Експериментальний пародонтит у щурів моделювали шляхом переведення їх на перекисну модель пародонтиту з додаванням до звичайного раціону харчування переокисненої соняшникової олії в дозі 1 мл на тварину [1].

Експериментальні запальні явища у шлунково-кишковому тракті відтворювали шляхом “іммобілізаційного стресу". Тварин протягом 10 діб щоденно фіксували на спині впродовж 6 год на спеціальному станку, фіксуючи кінцівки м'якими джгутами [3]. При проведенні експери- 
ментальних досліджень використовували 100 щурів 5-6-місячного віку масою 150-170 г. Перед введенням щурів у експеримент їх зважували, здійснювали ретельний зовнішній огляд та оцінювали поведінкові реакції кожної тварини. Кожна група містила однакову кількість різностатевих тварин з відхиленням від середньої маси щурів не більше $10 \%$.

Дослідження проводили з дотриманням загальних правил і положень Європейської конвенції про захист хребетних тварин, що використовуються для дослідних та інших наукових цілей (Страсбург, 1986), Загальних етичних принципів експериментів на тваринах (Київ, 2001).

Групи тварин виводили з експерименту одночасно. Евтаназію здійснювали під ефірним наркозом, шляхом кровопускання із серця, збирали сироватку крові. Вміст малонового діальдегіду (МДА), утвореного в процесі ліпопероксидації, визначали спектрофотометрично за реакцією з тіобарбітуровою кислотою. Активність каталази (КА) - за методом М. А. Королюка. Загальну протеолітичну активність (ЗПА) досліджували за методикою Мура-Штейна. Вміст білка у сироватці крові визначали за методикою Лоурі. Антиоксидантно-прооксидантний індекс (АПІ) обчислювали за формулою: $A П І=A_{\text {кат }} / C_{\text {мда }} \times 100$ [6], де $A_{\text {кат }}-$ активність каталази, $\mathrm{C}_{\text {мда }}$ - вміст малонового діальдегіду.

Отримані результати опрацьовували статистично.

РЕЗУЛЬТАТИ Й ОБГОВОРЕННЯ. На РИСУНКУ наведено результати дослідження біохімічних показників сироватки крові в експериментальних групах. Так, в інтактних щурів I групи вміст білка у сироватці крові складав $(0,74 \pm 0,07)$ г/л, що було на 32,43 \% нижче, ніж у тварин II групи, в яких було змодельовано експериментальний пародонтит $(p<0,05)$. у тварин III експериментальної групи, в яких запальні явища у шлунково-кишковому тракті викликали за допомогою "іммобілізаційного стресу”, рівень білка у сироватці крові становив $(1,18 \pm 0,07)$ г/л, що було на 59,46 \% більше даних в інтактних щурів I групи (p<0,01) та на $20,41 \%$ перевищувало значення у тварин II групи з модельованим пародонтитом $\left(\mathrm{p}_{1}<0,05\right)$. У піддослідних тварин IV групи, в яких моделювання пародонтиту поєднувалось із запальними явищами у шлунково-кишковому тракті, рівень білка в сироватці крові складав $(1,62 \pm 0,06)$ г/л, що було на 118,92 і $65,31 \%$ вище стосовно даних у щурів I та II експериментальних груп відповідно ( $\left.p ; p_{1}<0,01\right)$.
Рівень загальної протеолітичної активності у щурів I групи складав $(3,10 \pm 1,12)$ нкат/л, що було на 28,38 \% нижче стосовно відповідних значень у тварин з модельованим пародонтитом ( $>>0,05)$. В експериментальній групі щурів 3 модельованими запальними явищами в шлунково-кишковому тракті ЗПА становила $(4,06 \pm 1,12)$ нкат/л, що було на 30,96 і 2,01\% вище, ніж у піддослідних тварин I та II груп відповідно ( $\left.p ; p_{1}>0,05\right)$. У щурів IV групи, з поєднанням стоматологічної та соматичної патологій, ЗПА складала $(5,28 \pm 1,16)$ нкат/л, що перевищувало значення у I та II групах тварин на 70,32 та 32,66 \% відповідно ( $\left.p_{;} p_{1}>0,05\right)$.

В експериментальних тварин I групи вміст МДА у сироватці крові складав $(0,32 \pm 0,02)$ мкмоль/л при рівні каталази $(0,11 \pm 0,01)$ мкат/л, при цьому АПІ становив 34,38 .

У тварин з модельованим пародонтитом відмічали збільшення МДА в сироватці крові на $65,62 \%(p<0,01)$ при зниженні рівня каталази на 22,22 \% (p>0,05), причому АПІ зменшувався у 2,0 рази і становив 16,98.

У піддослідних тварин III групи, з модельованими запальними реакціями в шлунковокишковому тракті, відзначали збільшення вмісту МДА на 137,5 і 43,39 \% стосовно відповідних значень у I та II групах $\left(p ; p_{1}<0,01\right)$ при зменшенні рівня каталази на 83,33 і 50,0\% щодо значень в інтактних щурів (I група) та тварин II групи з модельованим пародонтитом $\left(p ; p_{1}<0,01\right)$. Слід зауважити, що в III групі щурів АПІ зі значенням 7,89 був у 4,3 і 2,0 рази нижчим, ніж у I та II групах відповідно.

У тварин IV групи, з експериментально модельованим пародонтитом і запальними явищами в шлунково-кишковому тракті, рівень МДА в сироватці крові був на 196,9 та 79,25 \% вищим, ніж у групі інтактних щурів і тварин II групи 3 модельованим пародонтитом $\left(p ; p_{1}<0,01\right)$. У цій же групі відзначали вагоме зменшення вмісту каталази в сироватці крові на 266,7 і 200,0 \% стосовно значень у I та II групах відповідно (p; $\left.p_{1}<0,01\right)$. При цьому АПІ в даній групі складав 3,16 , що було значно менше, ніж у піддослідних тварин I та II груп.

У результаті застосування запропонованого нами лікувально-профілактичного комплексу в піддослідних тварин V групи вдалося значно покращити показники біохімічних маркерів запалення у сироватці крові. Так, загальний рівень білка у сироватці крові щурів становив $(0,82 \pm 0,07)$ г/л при проведенні лікувальнопрофілактичних дій, що було на 19,51 \% менше, ніж у тварин II групи з модельованим пародон- 


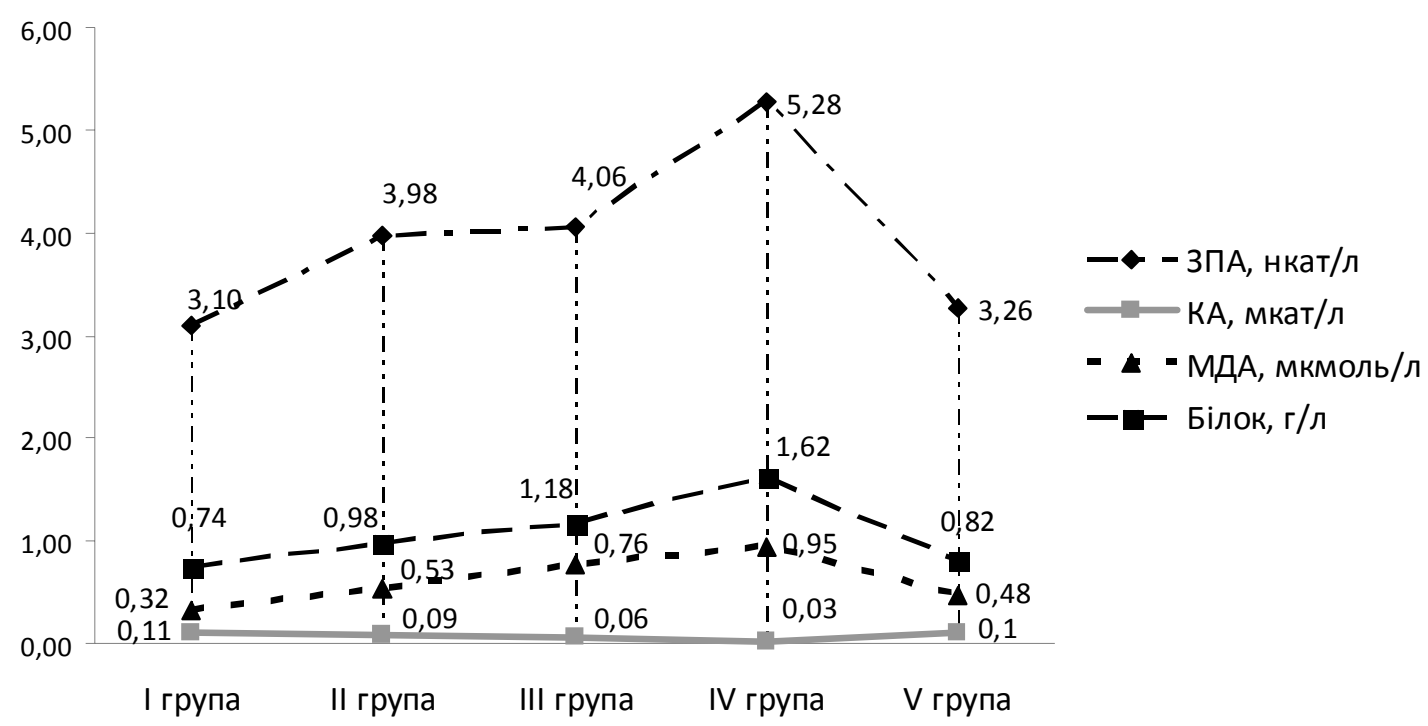

Рис. Динаміка змін показників біохімічних маркерів запалення в сироватці крові експериментальних тварин 3 модельованим пародонтитом на тлі уражень шлунково-кишкового тракту.

титом ( $\left.p_{1}>0,05\right)$, але на 10,81\% більше, ніж в інтактних тварин I групи ( $>>0,05)$.

Загальна протеолітична активність знизилась до $(3,26 \pm 1,17)$ нкат/л у процесі лікування та була на 22,09 \% меншою стосовно даних у щурів з модельованим пародонтитом $\left(\mathrm{p}_{1}>0,05\right)$, однак перевищувала аналогічне значення в інтактних тварин тільки на 5,16 \% (р>0,05). У результаті застосування розробленого нами лікувально-профілактичного комплексу вдалося значно покращити показники прооксидантно-антиоксидантного комплексу в V групі піддослідних тварин. Так, під час досліджень констатовано зменшення МДА до $(0,48 \pm 0,02)$ мкмоль/л, що було на 10,42 \% нижче, ніж у тварин 3 експериментальним пародонтитом ( $\left.p_{1}<0,01\right)$, але на 50,0 \% вище, ніж у щурів I групи $(p<0,01)$. Рівень каталази в експериментальних тварин V групи становив після лікування $(0,10 \pm 0,03)$ мкат/л, що було на $11,11 \%$ більше, ніж у II групі (p>0,05), але на 10,0 \% менше, ніж у піддослідних інтактних щурів I групи (p>0,05). Антиоксидантно-про-

\section{СПИСОК ЛІТЕРАТУРИ}

1. Генералізований пародонтит : монографія для студентів вищих навчальних медичних закладів, інтернів, лікарів-стоматологів, сімейних лікарів / Т. Д. Заболотний, А. В. Борисенко, А. В. Марков, І. В. Шилівський. - Львів : Галдент, 2011. - 240 с.

2. Годована О. І. Деякі аспекти етіології та патогенез запальних і дистрофічно-запальних захво- оксидантний індекс у V групі після застосування лікувально-профілактичного комплексу складав 20,83, що було в 1,2 раза вище від відповідного значення у II групі тварин, однак у 1,7 раза нижче, ніж в інтактних щурів I групи.

ВИСНОВКИ. у результаті проведення аналізу біохімічних маркерів запалення в сироватці крові тварин експериментальних груп з модельованим пародонтитом на тлі уражень шлунково-кишкового тракту найбільші процеси розбалансування біохімічних маркерів виявлено у IV групі тварин, в яких моделювання пародонтиту поєднувалось із запальними явищами у ШКТ, що переконливо засвідчує наявність підґрунтя для інтенсифікації запальних процесів у тканинах шлунково-кишкового тракту при поєднаній захворюваності.

Перспективи подальших досліджень. Заплановано розробити лікувально-профілактичний комплекс для корекції запальнодистрофічних процесів у тканинах пародонта на тлі шлунково-кишкових уражень з використанням природних факторів курорту Моршин.

рювань пародонту / О.І.Годована // Новини стоматології. - 2010. - № 3. - С. 69-73.

3. Дегтярова И. И. Клиническая гастроэнтерология : руководство для врачей / И. И. Дегтярова. М. : МИА, 2004. - 616 с.

4. Дерейко Л. В. Взаємозв'язок між пародонтитом і загальним станом здоров'я / Л. В. Дерейко, 
В. В. Плешакова // Імплантологія. Пародонтологія. Остеологія. - 2011. - № 2. - С. 76-83.

5. Заболотний Т. Д. Запальні захворювання пародонта : монографія для студентів вищих навчальних медичних закладів, інтернів, лікарів-стоматологів / Т. Д. Заболотний, А. В. Борисенко, Т. І. Пупін. - Львів : Галдент, 2013. - 205 с.
6. Камышников В. С. Справочник по клиникобиохимической и лабораторной диагностике / В. С. Камышников. - Минск, 2004. - 812 с.

7. Schein W. Helycobacter pylori and the mouth cavity - overview and perspectives / W. Schein, S. Meryn // Wien. Klin. Wochens chr. - 2004. - 17. P. 547-549.

И. Е. Швец, В. Т. Дырык, М. Т. Слобода ЛЬВОВСКИЙ НАЦИОНАЛЬНЫЙ МЕДИЦИНСКИЙ УНИВЕРСИТЕТ ИМЕНИ ДАНИЛА ГАЛИЦКОГО

\title{
ДИНАМИКА БИОХИМИЧЕСКИХ ПОКАЗАТЕЛЕЙ СЫВОРОТКИ КРОВИ У ЖИВОТНЫХ С МОДЕЛИРУЕМЫМ ПАРОДОНТИТОМ НА ФОНЕ ЭКСПЕРИМЕНТАЛЬНЫХ ПОРАЖЕНИЙ ЖЕЛУДОЧНО-КИШЕЧНОГО ТРАКТА
}

\begin{abstract}
Резюме
У животных групп исследования с моделируемым пародонтитом при экспериментально вызванных поражениях желудочно-кишечного тракта исследовали содержание в сыворотке крови белка, малонового диальдегида, каталазы; определяли общую протеолитическую активность и антиоксидантно-прооксидантный индекс. Установлено, что в группах экспериментальных крыс повышаются содержание белка, малонового диальдегида и активность протеаз при снижении активности каталазы и антиоксидантно-прооксидантного индекса, причем данная тенденция носит более выраженный характер у животных с моделируемым пародонтитом на фоне экспериментальных поражений желудочно-кишечного тракта.
\end{abstract}

КЛЮЧЕВЫЕ СЛОВА: пародонтит, желудочно-кишечный тракт, белок, общая протеолитическая активность, каталаза, малоновый диальдегид.

I. Ye. Shvets, V. T. Dyryk, M. T. Sloboda DANYLO HALYTSKYI LVIV NATIONAL MEDICAL UNIVERSITY

\section{DYNAMICS OF BIOCHEMICAL PARAMETERS OF BLOOD SERUM IN ANIMALS WITH SIMULATED PERIODONTAL DISEASE ON THE BACKGROUND OF EXPERIMENTAL DEFEATS OF THE DIGESTIVE TRACT}

\section{Summary}

In the animals of research groups with simulated periodontal disease at the experimentally caused defeats of the gastrointestinal tract investigated content in the blood serum protein, malonic dialdehyde, catalase. It was determined a general proteolytic activity and antioxidant-prooxidant index. It is found that in the groups of experimental rats content of the protein, malonic dialdehyde and activity of proteases increase on a background of decrease of activity of catalase and antioxidant-prooxidant index, at what this tendency is more pronounced in the animals with simulated periodontal disease on a background of experimental defeats of the gastrointestinal tract.

KEY WORDS: periodontal disease, gastrointestinal tract, protein, total proteolytic activity, catalase, malonic dialdehyde.

Адреса для листування: І. Є. Швець, Львівський національний медичний університет імені Данила Галицького, вул. Пекарська, 69, Львів, 79010, Україна. 